\title{
Geocement solidification technology for radioactive boron-containing liquid wastes
}

\section{HAILIN CAO ${ }^{1}$, LUQIAN WENG ${ }^{1}$ a, PAVLE KRIVENKO², SHAOBIN LI ${ }^{1}$, OLEG PETROPAVLOVSKII ${ }^{2}$}

\author{
${ }^{1}$ Advanced Materials Research Institute, Shenzhen Academy of Aerospace Technology, The Tenth \\ Kejinan Road, High-tech Zone, Shenzhen, P.R.China
}

${ }^{2}$ V.D.Glukhovsky Scientific Research Institute for Binders and Materials, Kiev National University of Civil Engineering and Architecture, Vozdukhoflotsky prospect 31, 03680 Kiev Ukraine

aleeweng_cl@chinasaat.com

\begin{abstract}
Keywords: Geocement, solidification technology, radioactive boron-containing liquid wastes
\end{abstract}
Abstract. The main problem of low-level radioactive wastes utilization in present technologies is lower waste containing capability and high leaching rates from the solidified body of compound. Also traditional OPC based grouts have low strength gain, especially at initial stages of hardening, caused mostly by influence of boron presence in the waste composition. The paper presents a solution to these problems by using geocement compositions, which provides bonding of radioactive elements not only in physical way, but also chemically by involving of elements into the new formations of cement stone. It has been show results of grout mix design of compositions with radioactive waste (RAW) content up to $20 \%$ by mass (in dry salts). The compositions under study met all the requirements for compressive strength (over 10MPa) and also shows very low leaching rates (leaching of Cs at 42 days of test $10^{-4}$ ).

\section{Introduction}

Current practice of radioactive waste management at nuclear power plants includes their conditioning, immobilization, for example, by cementation and placement in special containers with following disposal for long-term storage in engineered disposal facilities. The processes whereby a given batch of low-level radioactive or mixed radioactive and hazardous waste is converted to a single, solid piece are referred to as solidification. Prior to being solidified, the waste could be in a variety of forms, e.g., liquid, slurry (liquid plus suspended solids), etc. Solidification is accomplished by mixing the waste with a solidification agent or binder. The binder forms a monolithic solid by reacting chemically with the waste, by forming microscopic cells that encapsulate the waste, or by coating and binding the individual particles. A choice of radioactive waste solidification method should provide simplicity and reliability of operations, high productivity, minimal volume, reduced radiation exposure on personnel, easiness-to-repair and low cost of equipment. Of course, of first priority are properties of solidified waste forms in order to satisfy regulatory requirements.

\section{Experimental}

The initial salts were dissolved in water while heating them to a temperature of $90-100^{\circ} \mathrm{C}$ until a homogeneous solution was obtained. 
Table 1 chemical composition and characteristics

\begin{tabular}{|l|c|}
\hline \multirow{2}{*}{ Salts } & Liquid I \\
\cline { 2 - 2 } & Weight $(\mathrm{g} / \mathrm{l})$ \\
\hline $\mathrm{H}_{3} \mathrm{BO}_{3}$ & 69.2 \\
\hline $\mathrm{Na}(\mathrm{NO} 3)$ & 131.5 \\
\hline $\mathrm{NaCl}$ & 20.3 \\
\hline $\mathrm{Na}_{2}\left(\mathrm{SO}_{4}\right)$ & 18.6 \\
\hline $\mathrm{CaCl}_{2}$ & 2.5 \\
\hline $\mathrm{CuCl}_{2}$ & 2.4 \\
\hline $\mathrm{Fe}_{3} \mathrm{O}_{4}$ & 5.7 \\
\hline $\mathrm{Na}_{4}\left(\mathrm{C}_{2} \mathrm{H}_{2} \mathrm{O}_{4}\right)$ & 6.9 \\
\hline $\mathrm{Cs}\left(\mathrm{NO}_{3}\right)$ & 15.0 \\
\hline $\mathrm{Sr}\left(\mathrm{NO}_{3}\right)$ & 17.5 \\
\hline $\mathrm{Co}\left(\mathrm{NO}_{3}\right)$ & 13.2 \\
\hline $\mathrm{Salt}$ content, g/l & 302.8 \\
\hline Density of liquid evaporator concentrate, g/cm & 3 \\
\hline $\begin{array}{l}\text { Salts concentration of liquid evaporator concentrate, } \% \\
\text { by mass (calculated on dry matter) }\end{array}$ & 1.15 \\
\hline pH of liquid evaporator concentrate & 26.3 \\
\hline
\end{tabular}

Heating temperatures were selected to simulate temperatures of real evaporator concentrates after an evaporator which is intended for concentrating. Due to the fact that Liquid had $\mathrm{pH}=4-5, \mathrm{NaOH}$ was used to add alkalinity calculated from $40 \mathrm{~g} / \mathrm{l}$ of initial simulated evaporator concentrates, which were introduced in a dry form jointly with the binder (geocement). Used as the geocement components were: granulated blast-furnace slag (ggbs) with a fineness (expressed by a specific surface by Blaine- $4700 \mathrm{~cm}^{2} / \mathrm{g}$ ) and alkaline activators selected from $\mathrm{Na}_{2} \mathrm{SiO}_{3} \cdot 5 \mathrm{H}_{2} \mathrm{O}$ and $\mathrm{Na}_{2} \mathrm{CO}_{3}$. Used as calcium-containing additives were: $\mathrm{Ca}(\mathrm{OH})_{2}$ and Portland cement Class 42,5 CEM I.

The simulated liquid evaporator concentrate, which is to be solidified are stable only at temperatures higher than $60^{\circ} \mathrm{C}$. Because of this, after the simulated liquid evaporator concentrates are mixed with a binder (geocement) and in the process of grout preparation their temperatures will lower resulting in crystal formation. This will affect both properties of the geocement-based grouts (in particular, such as flowability, compressive strength, setting and hardening).

In order to reveal relationships of these factors 2-factor experiments have been designed and conducted. A numerical treatment of the results was done using a software product Statistica with the help of a PC X86 in accordance with [1-6]. Selected as basic factors (variables) were: temperature of the liquid evaporator concentrate, time during which the geocement was mixed with the liquid evaporator concentrate, flowability of the geocement-based grout. The compressive strength of the solidified waste form was taken as evaluation criteria. Compositions and characteristics of the geocement-based grouts are given in Table 3. 
Table 2 compositions and characteristics of the geocement-based grouts

\begin{tabular}{|l|c|}
\hline \multicolumn{1}{|c|}{ Constituents } & Contents, \% by mass \\
\hline $\mathrm{Slag}(\mathrm{ggbs})$ & 24.5 \\
\hline $\mathrm{Na}_{2} \mathrm{SiO}_{3} \cdot 5 \mathrm{H}_{2} \mathrm{O}$ & 6.1 \\
\hline $\mathrm{Na}_{2} \mathrm{CO}_{3}$ & - \\
\hline $\mathrm{Ca}(\mathrm{OH})_{2}$ & 5.1 \\
\hline $\mathrm{NaOH}$ & 1.6 \\
\hline $\mathrm{OPC}$ & - \\
\hline $\mathrm{Kaolin}$ & 15.3 \\
\hline Liquid evaporator concentrate & 47.4 \\
\hline L/G & 0.9 \\
\hline Dry salts concentration of solidified waste form, \% by mass & 12.5 \\
\hline Waste (liquid evaporator concentrate) loading, \% by volume & 63.7 \\
\hline
\end{tabular}

Table 3 Experimental design

\begin{tabular}{|l|c|c|c|c|c|}
\hline \multicolumn{1}{|c|}{ Input factors } & \multirow{2}{*}{$\begin{array}{c}\text { Units of } \\
\text { measurement }\end{array}$} & \multicolumn{2}{c|}{ Variation levels } & Variation \\
\cline { 3 - 5 } & & -1 & 0 & +1 & range \\
\hline $\begin{array}{l}\text { Temperature of liquid evaporator } \\
\text { concentrate }\left(\mathbf{X}_{1}\right)\end{array}$ & ${ }^{\circ} \mathrm{C}$ & 20 & 50 & 80 & 30 \\
\hline $\begin{array}{l}\text { Mixing time of geocement-based } \\
\text { grout }\left(\mathbf{X}_{2}\right)\end{array}$ & $\min$ & 3 & 7 & 11 & 4 \\
\hline
\end{tabular}

\section{Results and Discussion}

A multiple factor experimental design is given in Table 4. As a result of numerical treatment of experimental data the equations of regression to characterize the influence of temperature of liquid evaporator concentrate and mixing time of grout on flowability characteristics of grouts and strength of the solidified waste forms have been produced.

Table 4 design matrix and properties

\begin{tabular}{|c|c|c|c|c|c|}
\hline \multirow[b]{2}{*}{$\begin{array}{c}\text { No of } \\
\text { experiment }\end{array}$} & \multicolumn{2}{|c|}{ Design matrix } & \multicolumn{2}{|c|}{$\begin{array}{l}\text { Characteristics of the } \\
\text { geocement-based grout }\end{array}$} & \multirow{2}{*}{$\begin{array}{c}\text { Compressive } \\
\text { strength of } \\
\text { solidified waste } \\
\text { form, } \\
\text { Age }-28 \text { days, } \\
\mathrm{MPa}\left(\mathrm{Y}_{2}\right)\end{array}$} \\
\hline & $\begin{array}{l}\text { Temperature of } \\
\text { liquid evaporator } \\
\text { concentrate, } \\
{ }^{\circ} \mathrm{C}\left(\mathbf{X}_{\mathbf{1}}\right)\end{array}$ & $\begin{array}{l}\text { Mixing time of } \\
\text { geocement-based } \\
\text { grout, min }\left(\mathbf{X}_{2}\right)\end{array}$ & $\mathrm{L} / \mathrm{G}$ & $\begin{array}{c}\text { Flow value } \\
\text { (Vicat cone), } \\
\text { mm }\left(\mathbf{Y}_{\mathbf{1}}\right)\end{array}$ & \\
\hline 1 & 80 & 11 & 0.9 & 208 & 8.4 \\
\hline 2 & 80 & 3 & 0.9 & 177 & 9.3 \\
\hline 3 & 20 & 11 & 0.9 & 216 & 12.2 \\
\hline 4 & 20 & 3 & 0.9 & 205 & 13.4 \\
\hline 5 & 80 & 7 & 0.9 & 213 & 7.8 \\
\hline 6 & 20 & 7 & 0.9 & 217 & 12.8 \\
\hline 7 & 50 & 11 & 0.9 & 185 & 11.8 \\
\hline 8 & 50 & 3 & 0.9 & 205 & 9.7 \\
\hline 9 & 50 & 7 & 0.9 & 198 & 10.5 \\
\hline
\end{tabular}


The equations of regression are presented by the following relationships between the factors under study:

$$
\begin{gathered}
\mathbf{Y}_{1}=121,872+4,368 \mathrm{x}_{1}-0,054 \mathrm{x}_{1}{ }^{2}+26,035 \mathrm{x}_{2}-1,170 \mathrm{x}_{2}{ }^{2}-1,25 \mathrm{x}_{1} \mathrm{x}_{2}+ \\
+0,051 \mathrm{x}_{1} \mathrm{x}_{2}^{2}+0,015 \mathrm{x}_{1}{ }^{2} \mathrm{x}_{2}--0,0007 \mathrm{x}_{1}^{2} \mathrm{x}_{2}^{2} \\
\mathbf{Y}_{2}=21,147-0,445 \mathrm{x}_{1}+0,004 \mathrm{x}_{1}{ }^{2}-1,227 \mathrm{x}_{2}+0,026 \mathrm{x}_{2}{ }^{2}+0,07 \mathrm{x}_{1} \mathrm{x}_{2}-0,0019 \mathrm{x}_{1} \mathrm{x}_{2}{ }^{2}- \\
-0,0008 \mathrm{x}_{1}{ }^{2} \mathrm{x}_{2}+0,00003 \mathrm{x}_{1}{ }^{2} \mathrm{x}_{2}{ }^{2}
\end{gathered}
$$

Using the obtained numerical dependences, the relationship between these factors and their influence on properties of the geocement-based grouts and solidified waste forms have been portrayed in a plotted monogram (Fig.1 and Fig.2).
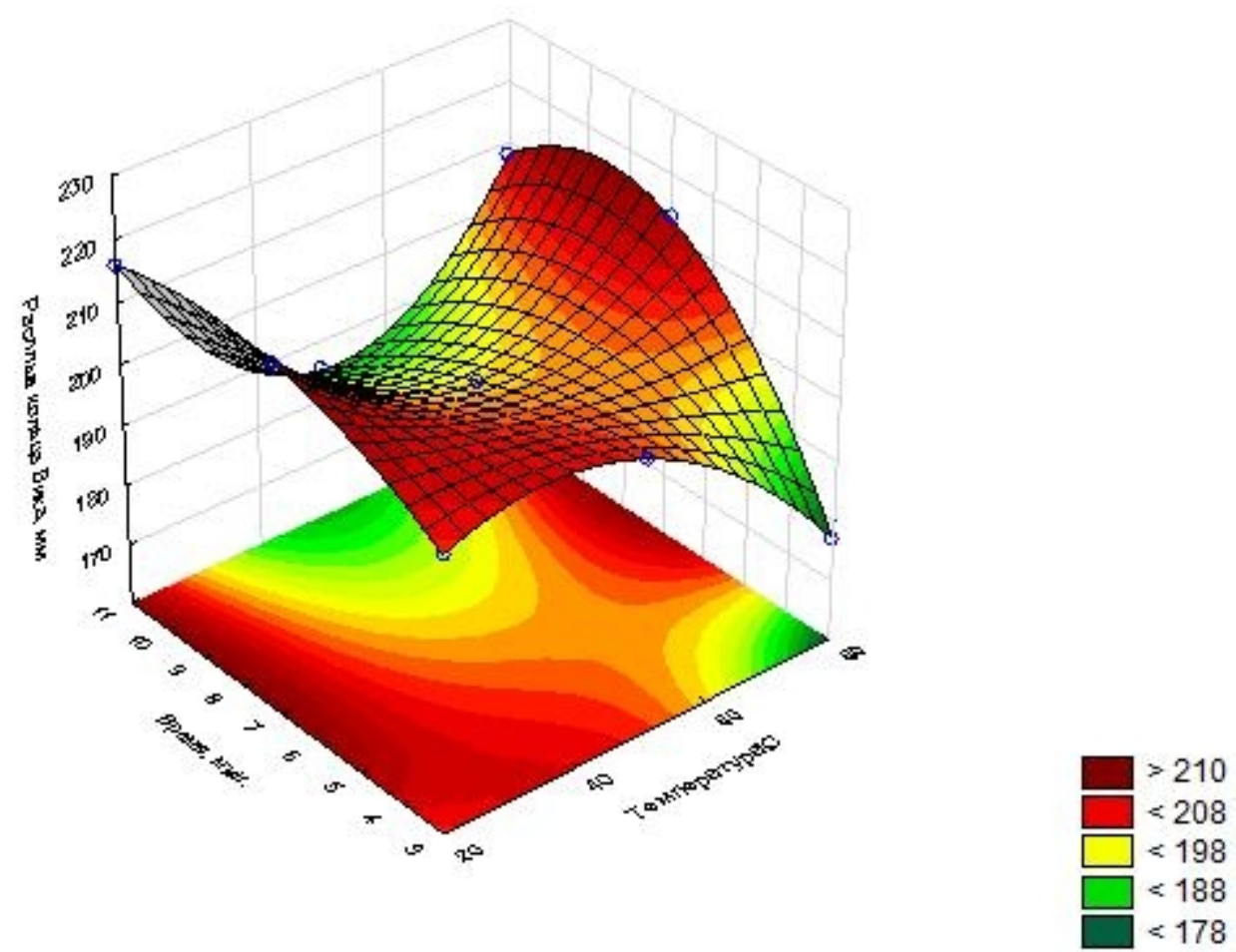

Fig.1. The influence of $\mathrm{X}_{1}$ and $\mathrm{X}_{2}$ on flowability of geocement-based grouts containing liquid waste.

As it follows from Fig.1, temperature $\left(\mathrm{X}_{1}\right)$ and mixing time $\left(\mathrm{X}_{2}\right)$ affect essentially flowability of the geocement-based grouts, which for the experiment varied between 177 and $213 \mathrm{~mm}$ (measured on a Vicat cone). A conclusion can be drawn that for temperatures of the liquid evaporator concentrate varying from 40 to $60^{\circ} \mathrm{C}$ and mixing time ranging between 5 and $7 \mathrm{~min}$ the prepared geocement-based grouts were characteristic of rather high flowability (flow value measured on a Vicat cone $=180-190 \mathrm{~mm}$ ) and homogeneity.

With temperature decline or increase beyond $40-60{ }^{\circ} \mathrm{C}$, as well as with shorter or longer mixing time, a viscosity of the geocement-based grouts tended to lower, what was associated with flow values reaching 200-217 $\mathrm{mm}$ (measured on a Vicat cone). It may result in spillage of the geocement-based grouts from the container (drum) with contamination of outer surfaces of mixing apparatus and mixing tools, what is not allowed. 

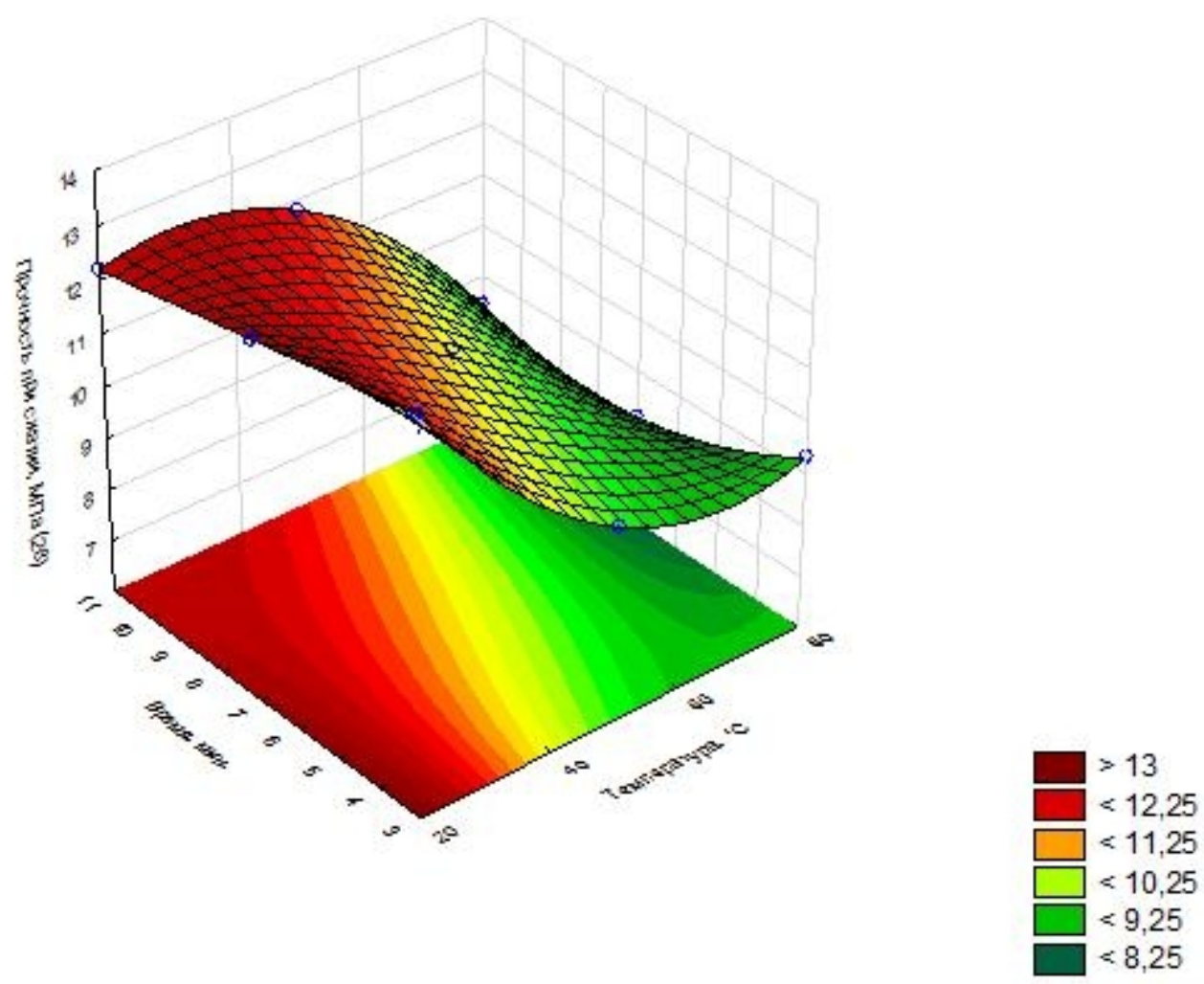

Fig. 2. The influence of $X_{1}$ and $X_{2}$ on compressive strength of the solidified waste form after 28 days of hardening.

This behavior of the geocement-based grouts can be explained as follows: in case of temperature decline of liquid evaporator concentrate by crystal formation and increase in free liquid content in the geocement-based grouts, whereas in case of temperature increase - by a plasticizing effect of fully dissolved salts. Analysis of the results given in Fig. 2 suggested to conclude that time of mixing of the geocement-based grouts had no influence on strength of the solidified waste form. The most important factor is temperature of liquid evaporator concentrate - with its temperature increase higher than $60^{\circ} \mathrm{C}$ a compressive strength of the solidified waste form after 28 days of hardening in normal conditions has lowered from 10.0-13.4 down to 7.8-9.3 MPa. Thus, basing on the obtained data a conclusion can be drawn that optimal solidification process parameters for liquid are:

- temperature of the liquid evaporator concentrate $-20-60{ }^{\circ} \mathrm{C}$;

- mixing time of the geocement-based grout - 5-7 min.

\section{Conclusions}

The results of work showed that in cementation of the liquid evaporator concentrate with dry salts concentration of $302 \mathrm{~g} / \mathrm{l}$ with providing the $\mathrm{L} / \mathrm{G}$ ratio of $0.90-0.92$, critical parameters from the point of view of workability of the geocement-based grouts and non-contaminant use of equipment and working tools due to possible spillage of the geocement-based grouts, is a temperature of the liquid evaporator concentrate. This temperature should be maintained within the temperature range of $40-60{ }^{\circ} \mathrm{C}$ and mixing time should between 5 to $7 \mathrm{~min}$. The meeting of these parameters allows providing a flowability of the geocement-based grouts within the range of 180-217 $\mathrm{mm}$ and strength of the solidified waste forms after 28 days of hardening $\geq 10 \mathrm{MPa}$.

The results of works allow for continuing with development of basic requirements for liquid radioactive waste cementation process design in a geocement matrix and development of recommendations on selection of basic equipment. 


\section{Acknowledgdments}

The authors are grateful for the support of Peacock Program funded by Shenzhen science and technology innovation committee.

\section{Reference}

[1] Varlakov A.P. Scientific Substantiation of Unified Cementation Technology for Radioactive Wastes. DSc Thesis. Moscow, 2011.

[2] Borovikov V. Statistica: An Art of Data Analysis Using Computer. Moscow: Piter Publish., 2003. 3.Kolmogorov A.N. Probability Theory and Mathematical Statistics. Moscow: Nauka Publish., 1986.

[3] Zedgenidze I.G. Experimental Design for Studying Multi-component Systems - Moscow: Nauka Publish., 1976.

[4] Nalimov V.V., Chernova N.A. Statistical methods for extreme experimental designs. Moscow: Nauka Publish., 1965.

[5] Voznesensky V.A. Contemporary Methods for Optimization of Composite Materials. - Moscow: Stroyizdat Publish., 1985.

[6] Nazarova M.G. General Theory of Statistics. Moscow: Omega-L Publish., 2010. 